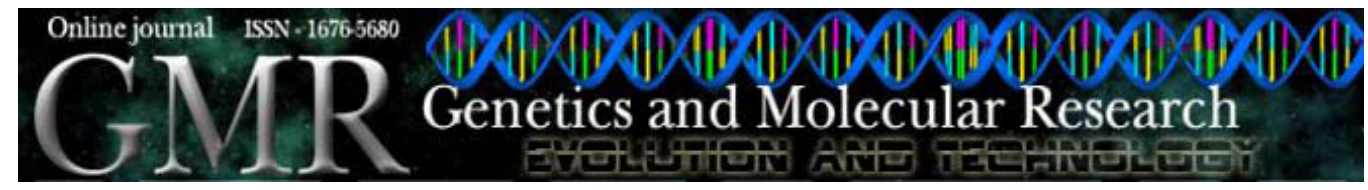

\title{
Development and characterization of polymorphic microsatellite markers in the gray mullet (Mugil cephalus)
}

\author{
T.-J. Xu, D.-Q. Sun, G. Shi and R.-X. Wang \\ Key Laboratory for Marine Living Resources and Molecular Engineering, \\ College of Marine Science, Zhejiang Ocean University, P.R. China
}

Corresponding author: R.-X. Wang

E-mail: wangrixin1123@126.com

Genet. Mol. Res. 9 (3): 1791-1795 (2010)

Received June 10, 2010

Accepted July 18, 2010

Published September 8, 2010

DOI 10.4238/vol9-3gmr909

\begin{abstract}
Using an (AG) $)_{13}$ enriched genomic library of Mugil cephalus, 12 polymorphic microsatellite loci were isolated and characterized in a test population; the number of alleles ranged from 2 to 11 . The observed and expected heterozygosities ranged from 0.2593 to 0.8966 and from 0.3047 to 0.8454 , respectively. Two loci deviated from Hardy-Weinberg equilibrium; linkage disequilibrium among the 12 loci was non-significant. These polymorphic microsatellite loci will be useful for genetic diversity analysis and molecule-assisted breeding of the gray mullet.
\end{abstract}

Key words: Mugil cephalus; Microsatellite; Molecular marker 


\section{INTRODUCTION}

The gray mullet, Mugil cephalus, commonly referred to as the striped, gray, or black mullet (Nelson et al., 2004), is a species that inhabits tropical and subtropical coastal regions of the world between $42^{\circ} \mathrm{N}$ and $42^{\circ} \mathrm{S}$ (Thomson, 1963). M. cephalus is an important commercial marine fish species for aquaculture in China (Li et al., 1998; Zhang et al., 2001; Zou and $\mathrm{Wu}, 2002$ ). This species can survive in both freshwater and sea water, which is significant for artificial cultivation both in coastal and inland regions. Hence, most Chinese studies on gray mullet have focused on its reproductive biology and breeding techniques (Li et al., 1998; Fang et al., 2001; Weng et al., 2001). In addition, to obtain information for the conservation of biodiversity, natural resources, and fishery management, allozyme analysis, biochemical markers and mitochondrial DNA sequences have been used in studies of the gray mullet (Crosetti et al., 1993; Rossi et al., 1998; Rocha et al., 2000, 2005; Huang et al., 2001). These studies mainly focused on the populations of gray mullet from the Mediterranean Sea, Atlantic Ocean and, to a lesser extent, East Pacific and Indian Oceans. Liu et al. (2009) used amplified fragment length polymorphism (AFLP) and the mitochondrial control region to characterize the population genetics of the gray mullet species along the coast of China.

Microsatellites, also known as simple sequence repeats (SSRs), are regions of DNA that exhibit short repetitive sequence motifs (Degnan and Arévalo, 2004). Microsatellites have been widely employed in population genetics studies of numerous species, and such application is continuously expanding (Kohlmann et al., 2005; Mia et al., 2005). These motifs are often composed of 1- to 6-bp repeats and high polymorphism occurs for different repeats. Because they are co-dominant and highly polymorphic, microsatellite DNA markers have been successfully used in revealing population genetic diversity (Sekino and Hara, 2001; Selkoe and Toonen, 2006; Liu et al., 2009). Although it is an important commercial fish species, only 11 polymorphic microsatellite markers have been reported (Miggiano et al., 2005). Lack of sufficient and polymorphic molecular markers has limited the development of molecular phylogeny, population structure and molecule-assisted selective breeding in this fish species. Therefore, in the present study, 12 polymorphic microsatellite DNA markers were developed using fast isolation by the AFLP of sequences containing repeats (FIASCO method) to enrich and develop the molecular information of the gray mullet (Zane et al., 2002).

\section{MATERIAL AND METHODS}

Thirty individuals of gray mullet were collected from the East China Sea. Total genomic DNA was isolated from the fin clips using the standard phenol-chloroform method with some modification, which was subsequently dissolved in $100 \mu \mathrm{L}$ TE buffer. An enriched partial genomic library for the repeat motif $(\mathrm{AG})_{13}$ was constructed, essentially using DNA from one individual and following the FIASCO protocol. In brief, genomic DNA was digested using the MseI restriction enzyme (MBI), and DNA fragments between 250 and $1000 \mathrm{bp}$ were isolated from a $1.5 \%$ agarose gel. These fragments were ligated to the adapters OligoA (5'-TAC TCA GGA CTC AT-3') and OligoB (5'-GAC GAT GAG TCC 
TGA G-3'), and then amplified by polymerase chain reaction (PCR) using MseI-N primers (5'-GATGAGTCCTGAGTAAN-3'). The genomic DNA fragments containing SSR were then captured by hybridization to $(\mathrm{AG})_{13}$ biotin-labeled probes. Captured fragments were ligated to pGEM-T vectors (Promega) and then cloned using the TOP10 compentent cells, following the standard protocol. Some of the positive clones $(\mathrm{N}=54)$ were screened via PCR with T7/SP6 primers, and sequenced using T7 primer on an ABI 3730 automated sequencer. Forty-nine clones were successfully sequenced, and 40 sequences contained sufficient repeat motifs. Some possessed only three to seven repeats, which held less potential for useful polymorphism. Primers for these loci were designed using the PRIMER PREMIER 5.0 software. Thirty primer pairs were designed from 30 sequences, as the remaining SSR were too close to the cloning site to design primers.

Polymorphism at each locus was determined using 30 individuals. PCR amplifications were carried out in $25-\mu \mathrm{L}$ volumes containing $2.5 \mu \mathrm{L} 10 \mathrm{X}$ PCR buffer, $1.5 \mathrm{mM}$ $\mathrm{MgCl}_{2}, 0.2 \mathrm{mM} \mathrm{dNTP}, 0.2 \mu \mathrm{M}$ of the forward and reverse primers, and $1.5 \mathrm{U}$ Taq polymerase (Takara). Cycling conditions were $94^{\circ} \mathrm{C}$ for 4 min followed by 30 cycles of $94^{\circ} \mathrm{C}$ for $40 \mathrm{~s}$, annealing temperature for $45 \mathrm{~s}$ (see Table 1), and $72^{\circ} \mathrm{C}$ for $40 \mathrm{~s}$, followed by 1 cycle of $72^{\circ} \mathrm{C}$ for $5 \mathrm{~min}$ and then holding at $4^{\circ} \mathrm{C}$. PCR amplification was performed on an ABI 9700 thermalcycler. Denatured amplified products were separated on 6\% denaturing polyacrylamide (19:1 acrylamide:bis-acrylamide) gels using silver staining. A denatured pBR322 DNA/MspI molecular weight marker (Tiangen) was used as a size standard to identify alleles. POPGENE32 (Yeh and Boyle, 1997) and ARLEQUIN 3.11 softwares (Schneider et al., 2000) were used to estimate the number of alleles, observed $\left(H_{\mathrm{O}}\right)$ and expected $\left(H_{\mathrm{E}}\right)$ heterozygosity, violation of Hardy-Weinberg equilibrium (HWE) expectations and genotypic linkage disequilibrium. All results for multiple tests were corrected using Bonferroni's correction (Rice, 1989).

\section{RESULTS AND DISCUSSION}

All thirty primer pairs were successfully amplified, except for two pairs (Muce24 and Muce-25), and 12 of these loci were shown to be polymorphic in the gray mullet. Details of the 12 newly developed microsatellite loci and variability measures across 30 individuals are summarized in Table 1 . The number of alleles per locus ranged from 2 to 11 , with an average of 5.9167 and $H_{\mathrm{O}}$ and $H_{\mathrm{E}}$ ranged from 0.2593 to 0.8966 and from 0.3047 to 0.8454 , respectively. The polymorphism information content $(P I C)$ per locus ranged from 0.2582 to 0.8339 , of which five loci indicated intermediate polymorphic information $(0.25$ $<P I C<0.5)$, while the other five loci, being highly polymorphic $(P I C>0.5)$, could be useful for further study of population diversity.

Hardy-Weinberg equilibrium probability tests showed that the majority of the 12 loci were at HWE, Muce-14 (adjusted $\mathrm{P}=0.0042$ ) being the exception. Strong deviations from HWE $(\mathrm{P}<0.01)$ were observed in Muce-37, possibly due to the presence of null alleles. In total, 60 pairwise tests for linkage disequilibrium among 12 loci were non-significant $(\mathrm{P}>$ 0.05 , adjusted $\mathrm{P}=0.0008$ ). These polymorphic microsatellite loci in the gray mullet will enable studies of genetic variation, population structure, conservation genetics, and moleculeassisted selective breeding of the gray mullet in the future. 


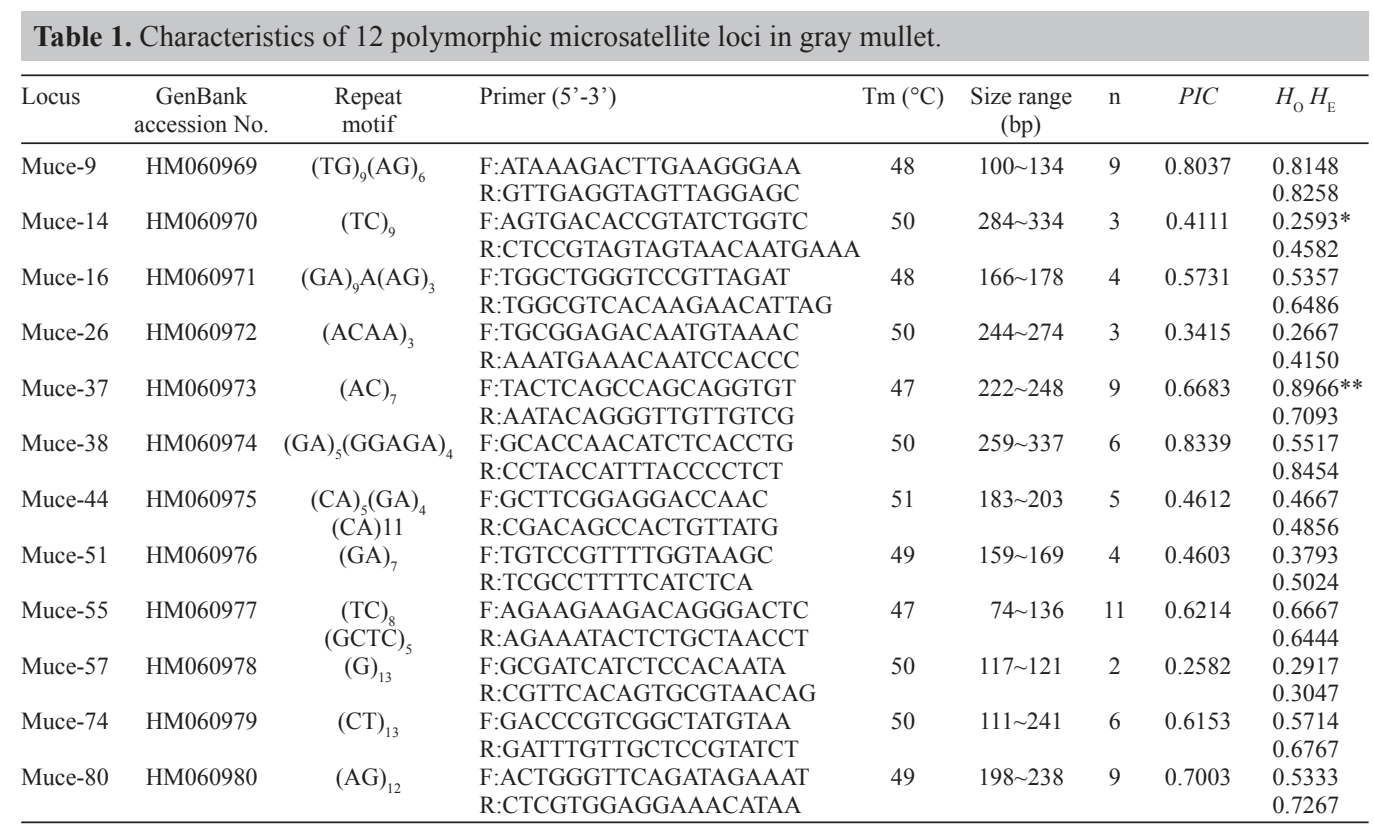

$\mathrm{F}=$ forward primer; $\mathrm{R}=$ reverse primer; $\mathrm{Tm}=$ annealing temperature; $\mathrm{n}=$ number of alleles; $P I C=$ polymorphism information content; $H_{\mathrm{O}}=$ observed heterozygosity; $H_{\mathrm{E}}=$ expected heterozygosity. *Significant departure from HWE $(\mathrm{P}<0.05)$. **Highly significant departure from HWE $(\mathrm{P}<0.01)$.

\section{ACKNOWLEDGMENTS}

Research supported by the Research Foundation of Zhejiang Province (\#2007C02001, \#2008C22026 and \#20070430) and the National Technology R\&D Program of China (\#2007BAD43B08).

\section{REFERENCES}

Crosetti D, Avise JC, Placidi F, Rossi AR, et al. (1993). Geographic variability in the grey mullet Mugil cephalus: preliminary results of mtDNA and chromosome analyses. Aquaculture 111: 95-101.

Degnan PH and Arévalo E (2004). Isolation of microsatellite loci in Sceloporus grammicus (Squamata, Phrynosomatidae). Am. J. Undergrad. Res. 2: 1-12.

Fang YQ, Weng YZ, Lin JZ, Hu XX, et al. (2001). Study on the cultivation of all-female in Mugil cephalus. J. Fish. Sci. China 25: 131-136.

Huang CS, Weng CF and Lee SC (2001). Distinguishing two types of gray mullet, Mugil cephalus L. (Mugiliformes: Mugilidae), by using glucose-6-phosphate isomerase (GPI) allozymes with special reference to enzyme activities. $J$. Comp. Physiol. B. 171: 387-394.

Kohlmann K, Kersten P and FlajÍhans M (2005). Microsatellite based genetic variability and differentiation of domesticated, wild and feral common carp (Cyprinus carpio L.) populations. Aquaculture 247: 253-266.

Li JE, Eou YJ, Ding YW and Zheng YM (1998). The reproductive biology of grey mullet pond culture in Guangdong province. J. Fish. Sci. China 5: 38-42.

Liu JY, Lun ZR, Zhang JB and Yang TB (2009). Population genetic structure of striped mullet, Mugil cephalus, along the coast of China, inferred by AFLP finger printing. Biochem. Syst. Ecol. 37: 266-274.

Liu YG, Chen SL and Li BF (2005). Assessing the genetic structure of three Japanese flounder (Paralichthys olivaceus) stocks by microsatellite markers. Aquaculture 243: 103-111. 
Mia MY, Taggart JB, Gilmour AE, Gheyas AA, et al. (2005). Detection of hybridization between Chinese carp species (Hypophthalmichthys molitrix and Aristichthys nobilis) in hatchery broodstock in Bangladesh, using DNA microsatellite loci. Aquaculture 247: 267-273.

Miggiano E, Lyons RE, Li Y, Dierens LM, et al. (2005). Isolation and characterization of microsatellite loci in the striped mullet, Mugil cephalus. Mol. Ecol. 5: 323-326.

Nelson JS, Crossman EJ, Espinosa PH, Findley LT, et al (2004). Common and Scientific Names of Fishes from the United States, Canada and Mexico. American Fisheries Society, Bethesda.

Rice WE (1989). Analyzing tables of statistical tests. Evolution 43: 223-225.

Rocha OA, Garber NM and Stuck KC (2000). High genetic diversity, large inter-oceanic divergence and historical demography of the striped mullet. J. Fish Biol. 57: 1134-1149.

Rocha OA, Arber NM, Garber AF and Stuck KC (2005). Structure of the mitochondrial control region and flanking tRNA genes of Mugil cephalus. (Estructura de la region control mitochondrial y genes ARNt adyacentes de Mugil cephalus). Hidrobiologica 15: 139-149.

Rossi AR, Capula M, Crosetti D, Sola L, et al. (1998). Allozyme variation in global populations of striped mullet, Mugil cephalus (Pisces: Mugilidae). Mar. Biol. 131: 203-212.

Schneider S, Roessli D and Excoffier L (2000). ARLEQUIN: A Software for Population Genetics Date Analysis, Version 2.000. Department of Anthropology, University of Geneva, Geneva.

Sekino M and Hara M (2001). Application of microsatellite markers to population genetics studies of Japanese flounder Paralichthys olivaceus. Mar. Biotechnol. 3: 572-589.

Selkoe KA and Toonen RJ (2006). Microsatellites for ecologists: a practical guide to using and evaluating microsatellite markers. Ecol. Lett. 9: 615-629.

Thomson JM (1963). Synopsis of Biological Data on the Grey Mullet (Mugil cephalus) Linnaeus, 1758. In: Fisheries Synopsis. Division of Fisheries and Oceanography, CSIRO Australia, Cronulla.

Weng YZ, Lin JZ, Fang YQ and Zhou J (2001). Further study on all-female cultivation of juvenile grey mullet Mugil cephalus. J. Oceanogr. Taiwan Strait 20: 547-552.

Yeh FC and Boyle TB (1997). Population genetic analysis of co-dominant and dominant markers and quantitative traits. Belgian J. Bot. 129: 157.

Zane L, Bargelloni L and Patarnello T (2002). Strategies for microsatellite isolation: a review. Mol. Ecol. 11: 1-16.

Zhang QY, Hong WS and Chen PX (2001). Status and prospects of artificial propagation and breeding technique of marine fush in Fujian. J. Oceanogr. Taiwan Strait 20: 266-273.

Zou JX and Wu GM (2002). The status quo and prospects of propagation and aquaculture of marine fish in Guangdong. Trans. Oceanol. Limnol. 84-93. 